\title{
Lusotopie
}

Recherches politiques internationales sur les espaces

issus de l'histoire et de la colonisation portugaises

XVIII(1) | 2019

Sport et nationalismes

\section{Lisbon's Estádio Nacional: An Adaptable Lieu de mémoire}

o Estádio Nacional de Lisboa: um Lieu de mémoire flexível

Le Stade national à Lisbonne: un lieu de mémoire flexible

David G. Frier

\section{CpenEdition}

Journals

Electronic version

URL: https://journals.openedition.org/lusotopie/3699

ISSN: 1768-3084

\section{Publisher}

Idemec - UMR 7307

\section{Printed version}

Date of publication: 12 March 2019

Number of pages: 40-65

ISSN: 1257-0273

Electronic reference

David G. Frier, "Lisbon's Estádio Nacional: An Adaptable Lieu de mémoire", Lusotopie [Online], XVIII(1) |

2019, Online since 02 January 2022, connection on 04 February 2022. URL: http://

journals.openedition.org/lusotopie/3699

This text was automatically generated on 4 February 2022.

Lusotopie 


\title{
Lisbon's Estádio Nacional: An Adaptable Lieu de mémoire
}

\author{
O Estádio Nacional de Lisboa: um Lieu de mémoire flexível \\ Le Stade national à Lisbonne : un lieu de mémoire flexible
}

David G. Frier

\section{Pierre Nora and his "lieux de mémoire"}

1 At a time when questions of physical representations of historical memory are being discussed across the globe, this paper will explore the Portuguese National Stadium, situated in the Jamor valley, on the western outskirts of Lisbon and constructed amidst great nationalist rhetoric by the "Estado Novo" (New State) in the 1940s. Why does this site still retain popularity amongst football fans both from Portugal and from other countries in view of its clear associations with the nationalistic ideology of a now discredited regime? I will base my argument on the notion of "lieux de mémoire" (realms of memory) defined by the French historian Pierre Nora as "the places in which the collective heritage of France was crystallized" (Nora 1996: xv). Whereas Nora's specific focus is on the historical memory of France, the term may be equally applicable to that of any imagined community: "a lieu de mémoire is any significant entity, whether material or nonmaterial in nature, which by dint of human will or the work of time has become a symbolic element of the memorial heritage of any community" (xvii).

2 Nora follows in the wake of Lefebvre's discussions of the social production of space (Lefebvre 1991), and, while Nora's work has been influential, there has been significant contestation of some aspects of it: Legg argues that his notion of "memory" is essentially a passive one, being all too easily overridden in his view by officially sanctioned versions of history, but also noting that even Nora himself concedes the survival of multiple different memories into the present (Legg 2004: 494), while de Certeau (and others) who have examined space in terms of palimpsestic views of history lay stress on the importance of individual subjectivity, claiming that "the memorable is that which can be dreamed about a place" (de Certeau 1984: 109) and 
Hutton (in a review of Barash) sees contemporary memory as under threat from new developments in media and technology, thus introducing a transnational rather than a merely national element into play (Hutton 2018: 298-299) while still recognising the seminal nature of Nora's original concept (304). While we may agree with Legg, therefore, that "Nora's emphasis on the nation seems increasingly out of place(s)" (Legg 2004: 500), it remains possible and productive to accept Nora's notion of the lieu de mémoire as a "symbolic element of the memorial heritage of any community" if we accept that social groups united by concepts other than nationality are equally capable of deriving a collective symbolic memory from a particular stimulus.

Nora's intention to promote a history of "Les France" was to be seen in terms of the "natural articulations of memory itself, which the historian can only approach by way of its divisions, its real or imaginary continuities, and its symbolic fixations" (Nora 1996: xvii-xviii):

Adopting such a view opens the way to a new kind of history: a history less interested in causes than in effects; less interested in actions remembered or even commemorated than in the traces left by those actions and in the interaction of those commemorations; less interested in events themselves than in the construction of events over time, in the disappearance and reemergence of their significations; less interested in "what actually happened" than in its perpetual reuse and misuse, its influence on successive presents; less interested in traditions than in the way in which traditions are constituted and passed on.

Nora 1996: xxiv

4 This exercise of collective memories lies at the heart of the surprising continued place of affection for the Estádio Nacional ("National Stadium") felt by football fans, within and beyond Portugal. To this end, I contend that we need to explore the material conception of the stadium and the precise mechanisms by which it was intended to convey a sense of national sentiment in the 1940s, as well as the constantly changing function of football (and sports in general) in Portugal over the decades since its opening in 1944. Above all, we must bear in mind Nora's stress on the "memorial heritage" of communities, treating the football stadium as a canvas for the memories of bodies of fans as "imagined communities" which, extending Anderson's familiar use of this term (Anderson 2006: 6), are often based around club loyalties rather than national ones.

In the absence of ethnographic studies of the attitudes of football fans over several generations, the methodology adopted in the present paper is largely based on the examination of contemporary newspaper reports, textual resources targeted at the fans of specific clubs, and official documents relating to the construction and the official opening of the National Stadium in 1944. Press reports are particularly valuable here, in accordance with the conclusions of Domingos and Kumar, who report that during the period under consideration in the present study, Portuguese newspapers and other media have slowly pushed an increasing "futebolização" (footballisation) of the sports media whose daily diet of news required an increasing focus on club rather than international football (Domingos and Kumar 2011: 257). This fact becomes particularly relevant when considering the weakening of the initial nationalistic sentiment associated with the National Stadium. 


\section{The Design of the Stadium and Its Opening Ceremony}

6 The National Stadium was conceived as part of the Estado Novo's broader architectural programme of (re)construction and (re)memorialisation of the nation, including the new monuments built at Belém for the Exposição do Mundo Português (Exhibition of the Portuguese-speaking World) of 1940. While the physical design of the stadium recalls arenas such as Hitler's Zeppelinfeld in Nuremberg (Cruz 2005: 104-105), ${ }^{1}$ it does not bear the prominent, explicit expressions of ideology in its construction which were apparent in many Fascist arenas of the time (such as the "Foro Mussolini", or Mussolini Forum, in Rome $^{2}$ ). Salazar's National Union saw itself as being above politics and explicit expressions of ideology of the Left or the Right, and, while, paradoxically this in itself is a deeply ideological position, it meant that such explicit markers of ideology as there are within the stadium are either discrete and small in size (for example, the Portuguese coats of arms and astrolabe designs on the rear doors to the Presidential Box above the main stand) or so subtle as to be barely visible to the casual observer: the use of "calçada portuguesa" (Portuguese mosaic paving stones) for example, in the approach to the stadium on its open (East) side is so ubiquitous in Portugal that it can easily be overlooked, although it fits neatly with Billig's concept of the (often unspoken) reminders of the nation surrounding us so much on an everyday basis that they cease to be visible as such (Billig 1995: 114-116).

7 Nonetheless, nationalist imagery was visible aplenty at the stadium during the lavish Opening Ceremony, held on the "Dia de Camões e da Raça" (Day of Camões and the [Portuguese] Race) on 10 June 1944, but this imagery was largely staged in performative terms rather than being an integral part of the design of the stadium itself: the propaganda was based on the performance rather than the stage, demonstrating the potential for healthy exercise within the body of the fit young Portuguese athlete: "a self-contained, well ordered, pliable and repressed body (white and male) whose sole objective was to serve the cause and the interests of the nation and preserve its wholeness" (Ornelas 2002: 66).

8 To this end, there was a long procession of representatives of different sports offering the Roman salute to the dictator Salazar and the National President as they passed the Presidential Box; there were displays of gymnastics by women from the FNAT ("Força Nacional pela Alegria no Trabalho", or National Body for Joy in Work), praised in the voice-over commentary on the propaganda film made of the occasion for their hygiene in preparation for their "altíssima função" (exalted calling) as mothers of future members of the state; there was a eulogy to Salazar delivered by an athlete from the INEF ("Instituto Nacional de Educação Física", or National Institute for Physical Education); and the tops of the stands around the stadium were adorned with flags borne by members of the "Mocidade Portuguesa" (Portuguese Youth), bearing the design not of the national flag of the 1940s, but the design used by the so-called "Inclita Geração" (Glorious Generation) which initiated the country's period of overseas exploration and expansion under Prince Henry the Navigator in the fifteenth century. Bearing in mind the relatively recent dual celebrations of the anniversaries of the foundation of Portugal as an independent kingdom in 1140 and the restoration of national independence in 1640, the message to be conveyed was clear: not only had Salazar ably guided the country through the Second World War without either 
endangering its independence or being dragged into the conflict, but the healthy invigoration of the race represented by the magnificent new stadium and its ancillary facilities was to launch a new era of greatness for pluri-continental Portugal, even in spite of the blatant metropolitan (and white) assumptions of the event. The impressive documentary film of the event made by a favoured director of the regime, António Lopes Ribeiro, enabled the performative aspect of the Opening Ceremony to be repeated in cinemas across the nation in subsequent days (see Ribeiro 1944).

\section{Sport and the (In)visibility of Nationalist Expression}

If the Opening Ceremony for the Stadium was intended to reinforce and to $s(t)$ imulate a memory and a message of a nation united in its mission in sport as in all other aspects of human life, the longer-term purpose of the complex at the Jamor was performance of another kind: while the Stadium itself could host major events such as international football matches, the facilities for participative (rather than spectator) sports such as athletics, rowing and tennis were intended to allow an increasingly urban population to escape from the noise and bustle of the city and enjoy the healthier air and beautiful surroundings of the area in a landscape deliberately designed to reproduce the environs of classical Greece. This concern for the health of the masses was still, however, political in nature, as Salazar's original justification for the Stadium project demonstrates:

Que pêna me faz saber aos domingos os cafés cheios de jovens, discutindo os mistérios e problemas de baixa politica, e ao mesmo tempo ver deserto esse Tejo maravilhoso, sem que nele remem ou velejem, sob um céu incomparável, aos milhares, os filhos dêste pais de marinheiros. Temos de reagir pela verdade da vida que é trabalho, que é sacrificio, que é luta, que é dor, mas que é também triunfo, glória, alegria, céu azul, almas lavadas e corações puros, e de dar aos portugueses, pela disciplina da cultura fisica, o segredo de fazer duradoira a sua mocidade, em beneficio de Portugal.... [R]egozijemo-nos, porque teremos em breve o Estádio Nacional!

(What sorrow I feel knowing that on Sundays the cafes are full of young people talking about the mysteries and problems of the minutiae of politics, while at the same time I see that magnificent Tagus deserted, and there are not thousands of these children of a land of sailors rowing in it or sailing on it. We need to react with the true response to life, which is work, which is sacrifice, which is struggle, which is pain, but which is also victory, glory, joy, blue skies, cleansed bodies and pure hearts, and through the discipline of physical culture we need to give to the Portuguese the secret of making their youth eternal, to the benefit of Portugal.... [R]ejoice, because we will soon have the National Stadium!) ${ }^{3}$

While a further ten and a half years passed before the opening of the stadium, it is important to note the conception of participative sport here as an exercise in training the body to respond to the functional needs of the nation and to leave matters of the mind (the discussion of political matters) to the symbolic Head of the nation (Salazar and his closer colleagues). The location of the stadium near the Tagus was intended to serve as a reminder of the greatness of the nation in whose name its youth were to prepare and maintain their bodies, with an implicit promise in Salazar's remarks of an elixir of immortality offered by the gods to recall the classical heritage into which he was seeking to insert his vision of the nation. 
11 Even if the arena (with its open side) permitted the visible entry of largescale processions such as those seen during the Opening Ceremony, these were to be passing events, with the Stadium and the complex as a whole reflecting the higher, Olympian values to which Portugal was laying claim, as the symbolic founder of a new era in civilisation. ${ }^{4}$ The official programme for the Opening Ceremony renewed the claims to semi-divine powers, stressing that the design was formulated to master time as well as space, in the name of the nation, with the careful planting of trees typical of southern Europe: "Por detrás da colunata, como sentinelas de glória, os loureiros simbólicos. Mais além, a mata mista, com os seus pinheiros de alepo, de cabeleiras desgrenhadas, e os seus eucaliptos, convidando às merendas amenas e suaves" ("Behind the columns, like a guard of honour, there are the symbolic laurels. Beyond that, the mixed forest, with its Jerusalem pines, with untended summits, and the eucalyptus trees, issuing an invitation to pleasant, gentle picnics") (O Estádio Nacional 1944: 13). Photographs of the site from 1944 show bare hillsides around the arena but some twenty years later, the pleasant woodland predicted was already clearly in evidence. ${ }^{5}$

All partisan sentiment was to be banished from the arena on a day-today basis, even (with occasional moments of exception, such as that of the Opening Ceremony) that of the very nation implicitly celebrated in the name of the Stadium; as Billig observes, the particular nation exalted is celebrated by the simple assumption of Portugueseness being the default setting for identity (Billig 1995: 93). In other words, it was possible for the type of nationalist sentiment associated with the Stadium to shift back and forth between Billig's concept of "banal nationalism" and a more assertive form of national feeling, not openly aggressive in nature (given the invocation made of the values of peace and national unity during the Opening Ceremony), but one which was, nonetheless, predicated on imperial values of domination: the invocation of the explorations of the past effaced the centuries-long domination of the nonwhite other within a pluri-continental nation, and even if the two major Lisbon football teams competed in exemplary fashion on the day for the "Taça do Império" (the Empire Cup), ${ }^{6}$ the reality of that Empire would erupt in less peaceful and pleasant form in Africa only seventeen years later, requiring the youth of the nation to sacrifice their bodies to something more threatening than the everyday requirements of work: "The call will already be familiar; the obligations have been primed; their words have long been installed in the territory of our pleasure" (Billig 1995: 125). In this sense, it does not matter that Billig's argument is primarily centred on contemporary Western democracies rather than more authoritarian regimes such as the Estado Novo, since the emphasis placed on the notion of the homeland during the Opening Ceremony was one in which the Portuguese audience was "invited to relax at home, within the homeland's borders" (Billig 1995: 127) and away from the confusion created elsewhere in Europe by the Second World War and which might have threatened the nation if anyone had been willing to risk the potential shaming of the perceived national essence by not aligning themselves with the nationalist sentiment given expression through the invocation of a glorious imagined past (Billig 1995: 101).

The Opening Ceremony took place only days after the Allied D-Day landings in Normandy (on 6 June 1944), and while there was an explicit intention that moments of high nationalist symbolism should be repeated, in practice the defeat of Nazi Germany rendered such exercises in blatant flag-waving more difficult to stage, even in a dictatorship such as Portugal's: although Agoas and Gomes report that nationalist 
propaganda leaflets were airdropped onto the crowd at the stadium during a Portugal vs. Spain international match held on 11 March 1945 (Agoas and Gomes 2011: 179), the propaganda value to be derived from the stadium in subsequent years was somewhat subtler, with A Bola's coverage of the 1967 European Cup Final, for example, permitting the high-ranking FPF official (and later President) Dr. Silva Resende to exalt the undeniably beautiful surroundings and idiosyncratic construction of the Stadium as a unique setting for such an event. ${ }^{7}$ Occasional football matches and other major events could be used to stimulate national sentiment, but these could backfire (as happened most notably with an embarrassing 10-0 defeat by England in May 1947, which led to open questioning in the press of the commitment of some players to the cause of the national team ${ }^{8}$ ). Billig's conception of nationalist expression in the sporting arena works well as a theoretical concept, but for such exercises to function effectively as soft power over the country's own citizens, the waving of flags and singing of national anthems at sporting events requires not only the "prior rehearsals and reminders" of duty to the fatherland to which he alludes (Billig 1995: 124-125) but also impressive performances on the pitch, something which the (officially) amateur status of football in 1940s Portugal made impossible to achieve in international terms. Ironically, according to Coelho and Pinheiro (2002: 677), it was only well into the period of democracy, with the appearance of the so-called Geração de Ouro ("Golden Generation") in the 1990s that the national team "tenha conseguido finalmente unir os adeptos portugueses, dado que os elementos destacados desta actuavam quase todos fora do país em grandes clubes europeus" ("managed to finally unite all Portuguese supporters, since the most prominent players in the team almost all played outside the country in big European clubs"): where Salazar's nationalist rhetoric failed, the television-fuelled capitalist boom in cosmopolitan recruitment at major clubs in richer Leagues succeeded, although Tiesler is probably correct to suggest that the national flags proliferating from private windows all over Portugal during EURO2004 were not comparable in significance to those waved to greet soldiers leaving for or returning from the Colonial Wars in the 1960s (Tiesler 2012: 337). In her view, these were something more like a utopian celebration of a Portugueseness unlikely to be realised in practice, and it could be argued that the real driving force here was money: the viability of the tournament required the maximisation of financial return for the significant investment made in it by the Portuguese state, the television advertisers and the football authorities, as discussed by Neves (2004: 71-78). ${ }^{9}$

\section{Professionalism and the Gradual Eclipsing of the National Stadium}

14 Even bearing in mind the reasons for the construction of the National Stadium and the pomp of its Opening Ceremony, its conception as a location for the expression (and the recollection) of nationalist feeling could barely have been maintained at the same level: the sporting world was to undergo rapid change in the decades following the Second World War, not least in the increasing prominence of club football, with implications for the specific nature of the memories which might become associated with the venue. The National Stadium came to be used only infrequently: the design adopted, with the Portuguese countryside visible on the open side of the stadium (following the model of Ancient Greek theatres) as a physical reminder of the national territory (Cruz 2005: 
104), had been intended to enable the crowd to see itself (and any dignitaries present in the Presidential Box) as a representation of the nation in the eyes of the nation itself (Billig 1995: 98), but, in the absence of mass political rallies and other sporting events capable of attracting large audiences in sports other than football, such opportunities rarely arose after 1944. In particular, as football grew in popularity during the 1950s, the rise of professionalism and the semi-autonomous nature of the management of the sport within Portuguese society as a whole led the three large clubs (Sporting and Benfica, in Lisbon, and FC Porto) to construct their own giant (and therefore more profitable) stadia inside the cities, closer to their largely urban support (see Serrado 2009: 114-124). The corinthian, participative ideals of sporting practice in Portugal, as envisaged by the regime, were quite simply incompatible with the type of modern commercial economy developing in the big cities: the idealistic rhetoric of politicians such as Bartolomeu Gromicho, railing against the social evils of what were perceived to be divisive club identities, were notable more for their refusal to face up to changing realities rather than for any real grasp of what was feasible at the time in the speaker's evident fear of the working class in movement:

[C]riou-se e acirra-se cada vez mais a animosidade entre as localidades, outrora em amistosas relações; fomenta-se e sustenta-se o ódio entre os associados dos vários clubes que se enfrentam. E o tão desejado intercâmbio turístico e recreativo das populações que se deslocam para ver os desafios transformou-se em viagensrelâmpago de agressividade e distúrbios, que se estão a tornar perigosos e indesejáveis para os poucos pacatos aficionados, que desejariam ver um espectáculo de destreza, de lealdade e de luminoso movimento.

([T]here has been created and aggravated an increasing sense of animosity between different places which previously enjoyed amicable relationships; hatred is whipped up and sustained between the supporters of the various clubs that compete with one another. And the recreational, tourist exchanges which were so much desired amongst the people who travel to watch matches have been turned instead into lightning journeys marked by aggression and disturbances, which are becoming dangerous and unpleasant for the handful of peaceable enthusiasts who would like to see a display of skill, teamwork and admirable physical movement). ${ }^{10}$

15 The impetus, however, was effectively irresistible: football was now an international phenomenon, and even if the government had wished to stop this growth in the football industry, it would have been unable to do so. As is well documented, the Estado Novo soon realised the propaganda value of international success for club sides such as Benfica and Sporting and the national team at the 1966 World Cup, not to mention the additional value to be derived from the star figure of Eusébio (representing Portugal) as a black Mozambican once the Colonial Wars were underway in Africa. The fears of outlier politicians such as Gromicho were realised in the sense of the growth of attachments to club sides, but the regime had no choice but to accept football as a spectator sport at the very least as a necessary evil and potentially as a celebration of national unity, particularly on the day of the Portuguese Cup Final, normally attended by the national President.

16 In the meantime, however, with the construction of club stadia around the country, routine, habit-forming footballing occasions took place away from the National Stadium, which was the regular home venue only for the national team and a site of annual pilgrimage for the Portuguese Cup Final throughout the dictatorship. Given the lack of success of the national team after the 1966 World Cup (Portugal did not qualify for another major international tournament again until the 1984 European 
Championships), Billig's note of caution about the sinister consequences arising from the inculcation of nationalist sentiment through the waving of flags at international matches was unlikely to have been realised through these channels in a Portugal engaged throughout the 1960s in a draining, unpopular and ultimately futile conflict in Africa. It is therefore no great surprise that Marcelo Caetano should have chosen one of the biggest club matches in the Portuguese footballing calendar (rather than an international fixture) for what was to prove to be his last appearance to a mass public audience before the 1974 Revolution took place. His brief gesture (waving to the crowd, to apparent public approval) at Sporting's Alvalade Stadium before a match against Benfica on 31 March 1974 may have appealed to him in terms of offering a large audience for promoting populist sentiment in his favour, but an RTP report indicates that the largely positive reception given to him on the day may have lulled him into a false sense of security regarding the possibility of any serious follow-up to the failed military uprising in Caldas da Rainha earlier in the same month. ${ }^{11}$ Yet the other vital context here is that this match took place in the latter stages of a hotly disputed championship race, in which the home team finished the season by reversing a run of three successive League Championship victories for their city rivals. Under these circumstances, Caetano's appearance to the crowd was unlikely to be the centrepiece of attention on the day in front of an audience more interested in the sporting event itself, and it is striking that the extensive reports on the match in A Bola on the day following the match make no mention whatsoever of Caetano's pre-match gesture. ${ }^{12}$ The instrumentalisation of sport in politics functions successfully only when the cause for which is it to be instrumentalised is perceived to be more urgent than the sporting event in itself.

\section{The 1969 Portuguese Cup Final and the April Revolution}

The architects and designers of the National Stadium may have had in mind a specifically nationalistic understanding of the memories to be evoked by the arena in the 1940s, but national (as well as personal) feelings can change over time, and the 1969 Portuguese Cup Final between Benfica and Académica de Coimbra allowed the student movement to recreate the imaginary of the nation according to its own needs rather than those prescribed by the state.

This particular match was a very different matter from the Lisbon derby of 1974: whereas the latter was between the two giants of football in Lisbon with a League title at stake, the 1969 match pitted one of the most prestigious clubs in Europe against a side which was technically an amateur student team, although for two or three years its football side had been one of the outstanding teams in the First Division. However the match mattered more to the supporters of Coimbra in connection with the student protests which had dominated life in the city in the early months of $1969 . .^{13}$ Once the University team reached the Final, the usual treatment of the match as a showpiece of national sport and symbolic national unity was abandoned, ${ }^{14}$ presumably for fear of the unthinkable (a victory, however unlikely, for the rebellious students): A Bola indicated tersely on the eve of the match that, contrary to many viewers' expectations, RTP would not televise the match live the following day. ${ }^{15}$ In addition, the national President, Américo Tomás, who had been photographed in A Bola alongside the players 
of Académica in their previous appearance in the Final in $1967^{16}$ declined to attend the match, and it is noticeable that (by way of contrast with customary practice) the only photo of the trophy in the reports on the match in A Bola after the event does not show the presentation itself in front of the dignitaries, but Eusébio (having swapped jerseys with one of his opponents after the match) kissing the trophy. ${ }^{17}$

The relatively liberal Diário de Lisboa newspaper (operating within the limits of state censorship) reported on the mass influx of supporters from Coimbra being applauded on the streets of the capital by locals,$^{18}$ and Eusébio was later to describe his winning goal in the match as "o golo mais triste da minha vida, por tudo o que estava, afinal, em causa" ("the saddest goal of my life, because of all that was at stake, after all"). ${ }^{19}$ On this occasion (when Benfica, no doubt to the relief of the government, won 2-1, having been losing 1-0 earlier in the match), the social and political meaning of the match was far greater than the result..$^{20}$ By contrast, Marcelo Caetano's attempt to stimulate a similar response on behalf of the dictatorship at Alvalade in March 1974 failed because it was an empty gesture, lacking in any deeper popular feeling: the greatest achievement of the students of Coimbra in June 1969 was to turn the rhetorical power of the Portuguese Cup Final, and by implication of the National Stadium, back against the regime which had attempted to impose its own set of meanings upon the venue quarter of a century earlier.

Since the April Revolution took place only thirty years after the Opening Ceremony of the National Stadium, it is no surprise that the annual Portuguese Cup Final was moved away from that venue after the Revolution: the 1974 final was still played at the Jamor, but in 1975 it took place at the ground of Sporting Lisbon. This was only the second time since the 1940s that the final had been played away from the National Stadium (Coelho and Pinheiro 2002: 522). The 1976 and 1977 finals were both played in Oporto, with Coelho and Pinheiro seeing the decision to play on the home ground of one of the contestants in 1977 (FC Porto) as being taken because the National Stadium was still "interdito pelas suas conotações fascistas" ("unacceptable because of its Fascist associations") (530), but reasons of convenience for supporters may have counted for as much as ideology, as both of these finals were contested by two teams from the north. Indeed, while the memory of the construction and design of the stadium undoubtedly played some part in this change of venue, it is striking that in the immediate aftermath of the Revolution, in its editions of 8 June and 10 June 1974 respectively previewing and reporting on that year's Cup Final, A Bola included no discussion of the suitability of the Jamor as a venue for the event, with the President of the FPF Jorge Fagundes reiterating in the edition of 13 June that it was his duty to always be present "no Estádio Nacional em dia de final da Taça" (at the National Stadium on Cup Final day). ${ }^{21} \mathrm{~A}$ further factor in the eventual return to the Jamor may have been of a commercial nature: in 1975 the Diário de Lisboa lamented the lack of live television coverage of the final between Benfica and Boavista, which attracted a relatively small crowd and the lowest gate receipts ever taken for a national cup final. ${ }^{22}$

21 In the meantime the "rehabilitation" of the stadium continued: in September 1977, the Portuguese Communist Party staged its annual Festa do Avante! (Avante! Festival, named after the Party's newspaper) in the National Stadium complex, thus reclaiming the site for a left-wing vision of the nation, ${ }^{23}$ and by 1978 , football supporters were certainly prepared to accept a return to the Jamor, where Sporting and FC Porto played in front of a large crowd (Coelho and Pinheiro 2002: 535), but the only controversy reported by 
Coelho and Pinheiro after the match lay in the refereeing of the Final and the replay (won by Sporting 2-1), with complaints from FC Porto of biased refereeing in both matches and the subsequent revelation that the referee in the second match had been invited to go on a tour of China with Sporting (Coelho and Pinheiro 2002: 535). This return to debates purely surrounding the internal politics of football indicated an ability on the part of Portuguese football supporters broadly to put aside ideological convictions and return to the loyalties which were perhaps more important to them on a daily basis, their club affiliations. Supporters of most football clubs choose to remember matches, particularly moments of success - and the revolutionary spirit aroused by and recalled today in connection with the 1969 Final would probably have been impossible with the participation of any team other than the relative underdogs of Académica de Coimbra, and even then only in the wake of student protests in Paris and elsewhere in the preceding year.

\section{The National Stadium Today: a "Proud Ruin" or a Site of Continuing Appeal?}

The continuing attraction of the site of the National Stadium for supporters of Portuguese clubs is readily visible in the frequent reference to the Portuguese Cup Final by allusion to the "Jamor" as a venue rather than directly to the match itself, thus reinforcing the relevance of Nora's conception of the lieu de mémoire. This trend is particularly noticeable in the case of smaller clubs who cannot realistically hope to present a sustained challenge to the "Big Three" in the League but who can visualise the possibility of occasional glories in the knock-out format of the Portuguese Cup competition: the commemorative DVD of the success of the unexpected winners of the 2018 tournament, Desportivo das Aves, is entitled CD Aves Rumo ao Jamor: O Filme (CD Aves Heading for the Jamor: The Film), with the actual occasion (the Cup Final) explicitly alluded to only in the small print of the description of the product on the club website. ${ }^{24}$ It is to be understood by the supporter that this commemorates the club's unexpected win over one of the "Big Three" (in this case, Sporting Lisbon), but there is no explicit mention made of that fact: instead, the "magic of the Jamor" conjures up the supporters' nostalgic memory of the day for sales purposes.

Seen in purely pragmatic terms as a venue for major football matches, the National Stadium leaves much to be desired, not having met minimum requirements set by FIFA and UEFA for staging competitive international or European club matches for many years. ${ }^{25}$ While the programme for the 1944 Opening Ceremony boasted, for example, of the uniqueness of this major arena having been hollowed out of a pre-existing dip in the landscape (and thus being in harmony with nature), ${ }^{26}$ this meant that ancillary facilities (for example press and media rooms, often housed below the stands of modern stadia), were seriously lacking (Coelho and Pinheiro 2002: 522). ${ }^{27}$ Recent highprestige footballing events in Portugal have been held at the stadia of each of the three major club sides in the country (the 2014 European Cup Final and the Final of Euro 2004 at Benfica's Estádio da Luz, the 2005 UEFA Cup Final at Sporting's Novo Alvalade, and the opening match of Euro 2004 at Porto's Estádio do Dragão), thus further calling into question the relative prestige of the National Stadium, while even in early discussions regarding Lisbon as a host for the European Cup Final as long ago as the mid-1960s, A Bola reports that the FPF initially had no intention to stage the match at 
the Jamor, citing only Sporting and Benfica's stadia as options to be considered by UEFA. ${ }^{28}$

The National Stadium, of course, is a neutral venue, so that there is no home advantage when two of the "Big Three" meet in a Portuguese Cup Final. Yet the magic of the Jamor consists in more than this, with the Diário de Aveiro, for example, referring to the 1999 Final (featuring the local team, SC Beira Mar) as being held in the "Vale do (J)amor". ${ }^{29}$ Part of the explanation for this lies in the idyllic setting of the stadium: this natural beauty survived throughout the regime and beyond, with the 1967 Cup Final between two provincial teams (Vitória de Setúbal and Académica de Coimbra) leading the society weekly $O$ Século Ilustrado to write in hyperbolic terms of the Sado and Mondego rivers flowing on the day of the Final into the Jamor in waves of "entusiasmo, de alegria e desportivismo desapaixonado" "of enthusiasm, of joy and of dispassionate sportsmanship"), thus implicitly stressing the nationwide relevance of an event traditionally dominated by the big-city clubs. ${ }^{30}$ Meanwhile, on the return of the final to the Jamor in 1978 after a three-year period of being played at club stadia, A Bola reiterated some of the pre-revolutionary rhetoric of the Official Programme of 1944, celebrating the return to tradition by alluding to Portuguese social customs: "sob as frondosas árvores do Estádio, espalhavamse quiosques improvisados de comes e bebes, que isto de ser português aqui tem sempre as suas implicações com a barriga" (under the leafy trees at the Stadium, there were improvised refreshment stalls scattered about, since being Portuguese here always makes its demands on the belly); the continued strictly national dimension of the event (even under a new political regime) was reinforced by an Opening Ceremony involving a parachute jump staged by the Portuguese Air Force to plant the flags of the nation, the FPF and the two competing clubs in the ground at the stadium. ${ }^{31}$

One particularly hyperbolic prediction made in the Programme for the Opening Ceremony of 1944 has been fulfilled more rapidly than the anonymous author of these lines may have realised: "O Estádio - que é uma obra acentuadamente nacional - foi construído para hoje e para o futuro. Mesmo daqui a muitos séculos, poderá dar ainda uma ruína orgulhosa!" "“The Stadium - which is a markedly national project - was built for today and for the future. Even many centuries from now, it will still be able to serve as a proud ruin!") (O Estádio Nacional 1944: 13). The implicit comparison to ruined structures such as the Acropolis is an apt one: even if the Stadium is little used now for high-profile sporting purposes, it retains its fond place in the imagination of fans of those Portuguese football teams who have tasted success there. In the end it is the occasion which makes the stadium, not its architecture, and the importance of memory is therefore vital in understanding the meanings which are held by the site.

\section{Club Loyalties as "Imagined Communities": Sporting Lisbon 2015}

Although Nora's conception of realms of memory lays particular stress on the national dimension within the human imagination, it is important to note how particular loyalties may nuance a tradition originally conceived of in a national context. I shall do so by examining one specific case relating to the experiences of a supporter of Sporting Lisbon in relation to the new form given in our own times to the "merendas amenas e suaves" foreseen in the Programme of the Opening Ceremony for the use of the 
woodland surrounding the National Stadium. Lopes' account of a season (2014-15) following Sporting Lisbon culminates in a chapter celebrating the club's first major trophy for eight years, a dramatic victory on penalty kicks over Sporting Braga, in spite of the team from the capital having faced a two-goal deficit with only six minutes remaining and having played most of the match with only ten men on the pitch (Lopes 2015: 147-153). The sense of euphoria communicated in this account will be familiar to any who have followed sports teams with enthusiasm. However, what is particularly interesting here is the modern twist attributed by the supporters of Sporting to the original conception of the Jamor, echoing the poetic language of the seventy-year-old descriptions of the stadium in Lopes' own version of events:

Observo tudo lá muito de cima, do velho Olimpo dos estádios, hoje em desuso, onde se reuniam os deuses anónimos do futebol, os adeptos comuns, cuja voz conjunta impunha os ritmos do jogo ao sabor dos aplausos e dos apupos. [...] Com o arvoredo em fundo e mais perto do céu amplo e azul de um Verão que se anunciava, com a solenidade vetusta conferida ao cenário pela pedra austera do estádio em anfiteatro, percebi como, ali e visto dali, o jogo se transforma.

(I watch everything from away up there, from this ancient Olympus of stadiums, now abandoned, where the anonymous gods of football used to meet, the ordinary supporters, whose voices in chorus forced the rhythm of the play with their applause and their boos. [...] With the wooded groves as a backdrop reaching up to the broad blue skies of approaching summer, with all the solemnity of old bestowed on the scene by the bare stone of the stadium like an amphitheatre, I was able to see up there and from up there, how the game was changing.)

Lopes 2015: 150

These words echo the praise for the Classical design of the stadium and its natural surroundings in the Programme of the Opening Ceremony, as well as its future projection of the stadium as a "proud ruin", and even Salazar's invocation of the blue summer skies of Portugal in his speech of 1933, but the emphasis throughout this chapter is on being a "leão" (a "lion", an allusion to the popular nickname for the club), an "eterno presente sportinguista" ("an eternal present as a Sporting supporter", alluding to the renewal of feelings obtained in past triumphs, and looking forward to further ones in the future) (Lopes 2015: 151), a "tertúlia e banquete sportinguista" ("a gathering and feast of Sporting supporters") (150), and - without naming them - an implicit goading of the club's eternal rivals, Benfica: "Podem falar do campeonato, que é muito bonito, e é, e temos que o ganhar, mas quem me tira esta festa tira-me tudo" ("'You can talk all about the Championship, which is fine, and it is, of course, and we need to win it, but if you take this party away from me, you're taking everything away") (150). There is also a very brief acknowledgement that somewhere else in the same forest supporters of Sporting Braga will have been having their own similar party, but they are incidental and are seen only at the last minute: "A multidão na mata começa a convergir para as entradas do Estádio Nacional. Nele entrados vemos finalmente os bracarenses, que terão tido festa semelhante à nossa noutro canto da mata" ("The crowd in the forest begins to gather around the entrances to the National Stadium. Once we are in there, we finally see the supporters from Braga, who will have had a party similar to our one in another part of the forest") (151).

The "merenda" foreseen in 1944 has become an alcohol-fuelled party, where the "coração bucólico do Jamor" ("bucolic heart of the Jamor") has been taken over by a stage with a DJ playing high-volume "hinos roqueiros de apoio ao Sporting e música techno e trance, como em rave" ("rock-style anthems in support of Sporting along with 
techno and trance music, as if it were a rave") (Lopes 2015: 147), and soon the barbecues are roasting sardines, sausages and "bifanas" (pork steaks), while the supporters have bottles of beer in their hands as early as 8.30am on the day of the match (148). The scene is captured graphically on the back cover of the book with a cartoon loosely based on Manet's painting of 1863 Le déjeuner sur l'herbe ("Luncheon on the grass"): the idyllic woodland setting of the painting is preserved, along with Manet's naked woman, but the two men wearing suits in the painting now pose in replica Sporting Lisbon shirts, while two men approach carrying a green-and-white flag and the foreground is taken up by a populist Portuguese scene of fifteen men (some black, some white) and a small child, all wearing club colours, gathered round a sucking-pig roasting on a barbecue. Other than the naked woman, no female figure is visible in this illustration: the emphasis is on the eternal values of a club-based, malebonding loyalty, with the small child representing future successes to come. The "merendas amenas e suaves" envisaged in 1944 as part of a life lived in a specifically Portuguese setting in Salazar's land of "brandos costumes" ("gentle routines") have been transformed into orgies of consumerist culture and high-tech entertainment associated with a specific loyalty, to Sporting Lisbon and not to Sporting Braga or any other club in Portugal. The spirit of partisan identity feared by Gromicho as a rival to purely national loyalties is celebrated, even if the venue of the National Stadium and its wooded surroundings continues to supply the form and the stage for the performance of a less wide-ranging identity than the one dressed up by Salazar and Marcelo Caetano as being all-inclusive (even if it applied in practice fully only to citizens of European Portugal).

\section{The National Stadium as Flexible Stage for Subjective Memory}

This is merely a demonstration of the continuing hold of the National Stadium over the imagination of one fan: supporters of other clubs will also hold many memories of notable triumphs in the stadium, and, for less prestigious teams unaccustomed to participation in European tournaments or winning the League Championship, the memory of any victory at the Jamor undoubtedly outweighs any political baggage which may still linger at the site. The historically small club from Aveiro, SC Beira Mar, for example, celebrated its greatest moment at the National Stadium on 19 June 1999, winning the Portuguese Cup with a 1-0 victory over Campomaiorense. The sense of local meaning surrounding the event is conveyed by the match preview in the Centro Portugal Desporto supplement of the Diário de Aveiro on the eve of the match, which reported an "Onda Amarela" (yellow wave) descending on Lisbon for the match: "Algo como um quarto de sua população residente [...] um apoio e um número de adeptos que certamente nunca teve nas últimas épocas, sempre que jogou... em Aveiro" (Something like a quarter of the residential population of the city [...] a support and a number of fans which it has certainly never had in recent seasons, anytime that the club has played... in Aveiro), ${ }^{32}$ while in an earlier preview of the match the club President, Marco Nunes, had encouraged the club's supporters to travel to the Jamor (specifically named as such and not as the National Stadium), in the hope that they would offer "uma grande lição de beiramarismo e aveirismo" (a fine example of the spirit of SC Beira Mar and the city of Aveiro). ${ }^{33}$ For supporters of smaller clubs, and, by association, for the 
people of the communities which they represent, then, the Jamor serves as a National Stadium not so much in any nationalistic sense but as a space where specifically local identities can be performed and (however briefly) given some attention on a national stage which routinely favours the big cities and the traditionally larger clubs. This is summed up by the emphasis placed by the Diário de Aveiro on the "leitões da Bairrada" (Bairrada sucking-pigs) as the "grandes sacrificados da festa" (principal sacrifices at the feast) in the pre-match gathering in the same forest at the Jamor celebrated by Lopes sixteen years later: the secular version of the feast of the Eucharist is given a specifically local, Aveiro twist by the prominent visibility of the regional speciality being sacrificed at one of the symbolic altars of the nation. ${ }^{34}$

The importance of memory in relation to the National Stadium is reemphasised by the significance of the venue in the memory of supporters of two foreign clubs: Torino of Italy, for whom the stadium is a site of mourning, and Celtic, from Scotland, who enjoyed their greatest moment of triumph in winning the European Cup there on 25 May 1967, defeating the favourites, Internazionale of Milan, 2-1, in a memorable match, which has ensured that the National Stadium in Lisbon is firmly entrenched as a focus for group identity in the minds of Celtic supporters, with countless fan websites, Twitter accounts and Facebook pages reproducing images of either the match itself or the empty stadium. ${ }^{35}$ Indeed, the fiftieth anniversary of this triumph saw a mass invasion of the stadium by some 1000 Celtic supporters (many of them born long after 1967), with club anthems being played over loudspeakers and a victorious ride around the running track by a group of sponsored cyclists who had ridden from Glasgow to Lisbon for the occasion; permission was even given to one supporter to scatter the ashes of three deceased supporters on the grass at the edge of the arena. ${ }^{36}$ Earlier in the same year, the club itself arranged for a commemorative plaque of the event to be placed outside the dressing-room area. ${ }^{37}$ As Woods remarks, "For the club and its fans, then, the Estádio Nacional will forever be Celtic's Elysian Fields" (Frier and Woods 2017: 86).

31 By way of contrast, however, the National Stadium holds very different associations for supporters of Torino, since it was the venue for the very last match played by the "Grande Torino" (Great Torino) team of the 1940s, which was wiped out almost in its entirety in the air crash at Superga, on the outskirts of Turin, on the return journey from playing a benefit match for the Benfica captain Francisco Ferreira on 3 May 1949. The occasion was recalled when Torino returned to Lisbon for the first time since that date to take part in the showpiece Eusébio Cup in July 2016, with the unveiling of a commemorative plaque at the stadium in the presence of officials and fans of both clubs on 27 July 2016. Benfica also maintain a section of the club museum at their own Estádio da Luz dedicated to Il Grande Torino, and the depth of feeling attached to this memory for supporters of the Italian club was reflected in press reports at that time. ${ }^{38}$ Both in this case and in that of Celtic, there may be little specifically Portuguese memory attached to the National Stadium, but, once again, as has been observed in the examples given relating to SC Beira Mar, Desportivo das Aves, Académica de Coimbra and Sporting Lisbon, the memory of the moment provokes subjective, emotional responses which have less to do with the objective structure or design of the site and more (in Nora's words) "in the construction of events over time, in the disappearance and reemergence of their significations" (Nora 1996: xxiv), a constant remembering of events past of significance to identity in the present. 

of emotion (be it positive or negative) attached to particular moments, with the venue for these moments supplying the prompt for the stimulation of these emotions: importance lies in the shared moment itself, celebrated (or, in the case of supporters of Torino, mourned) as part of the experience of being a member of a particular community. In his discussion of the rise of the Portuguese sporting press from the 1940s onwards (with particular reference to mass-circulation newspapers such as A Bola or Record), Neves (echoing Anderson's notion of the "imagined community") stresses the media contribution to the stimulation of a virtual national community where no individual reader can ever know all of its other members, but where experiences can be shared across the country more or less simultaneously through the papers' widespread readership, a tendency which has been accentuated by the growth of television coverage of matches involving clubs from all over the country in recent decades (Neves 2004: 62-63). As regards the National Stadium itself, for a brief moment in the mid-1970s the site was seen primarily as a relic of excessive nationalistic rhetoric and a detested (and now abolished) political regime; however, only a few years earlier, in 1969, the students of Coimbra had transformed Salazar's arena for bombastic nationalist rhetoric into a site of overt contestation of the dictatorship. Viewed in that light, the stadium itself has no inherent meaning other than that which particular subjectivities impose onto it: a "symbolic element of the memorial heritage of any community" (Nora 1996: xvii) does not require a top-down prescription of national identity, and it may instead be given expression by any community (usually, but not necessarily, Portuguese) which finds the site meaningful to it.

In the sporting context, particularly with the relative invisibility of overtly nationalistic images within the stadium itself, it is the emotions shared within a particular imagined community which matter, but, in spite of Anderson's highlighting of nationalism as a powerful force in the world today (and Billig's fears of the uses to which nationalist sentiment may be turned), it is important to recognise that identities are formed around much more than nationality (race, gender and sexual orientation, for example, can be as powerful for individuals as nationality). Football clubs are merely one other possible form of group identity (and one which escaped the attention of either Anderson or Billig, both writing in the mid-1990s, before the more recent boom in fan culture as a widely recognised genre of writing), and the National Stadium complex beyond the stadium itself (not least with its important functions in developing participative sports for all sectors of Portuguese society) clearly has a wide range of associations for Portuguese citizens in the twenty-first century, regardless of the circumstances in which its construction was undertaken. If club loyalties have gained prominence over national ones in recent decades, it is nonetheless on the national stage that all Portuguese clubs find the opportunity to achieve tangible success in the form of trophies: the National Stadium functions in the popular imagination primarily as a national rather than as a nationalistic stage, with no claims being made through the site today regarding Portugal's role in the wider world, whatever residual memory there may be of the flags flown at the Opening Ceremony in 1944. Portugal, then, is merely the context in which one's chosen club side performs.

The relative weakness of the Portuguese national football team during the bulk of the dictatorship did not lead in general terms to an association of the national team with the patriotic hyperbole of the regime, so that the memories associated with the site are 
more likely to be based on club loyalties than on ones associated with high moments of national pride, which cannot necessarily be sustained indefinitely. Where an architectural site attempts to impose a monolithic vision of the nation and/or of history, the reality of the way that memory functions is that space can easily become a contestation of that authoritarian understanding, because memory is fluid and multiple, as is amply demonstrated by the memories of events such as the 1969 Portuguese Cup Final at the Jamor. Even the idyllic surroundings of the stadium are no longer perceived, at least by Lopes and by the journalists of the Diário de Aveiro in 1999, as being specifically attached to Portugueseness, but to moments of achievement for their respective clubs. If the National Stadium serves as a "lieu de mémoire", then that memory does not have to be a specifically national one (in the sense of a static, patriarchal view of the nation): the term "Nacional" in the name of the arena effectively has come to signify openness to memories of all kinds, on the part of past users of the stadium, Portuguese and foreign.

\section{BIBLIOGRAPHY}

Agoas, F. and Gomes, P. D. 2011, “Contributos para uma genealogia do estádio de futebol em Portugal: arquitectura, Estado e cultura de massas", in J. Neves and N. Domingos eds., Uma história do desporto em Portugal, t. I, Corpo, espaços e média, Vila do Conde, Quidnovi: 167-192.

Anderson, B. 2006, Imagined Communities: Reflections on the Origin and Spread of Nationalism, revised edition, London, Verso.

Andresen, T. 2003, “Três Décadas de Arquitectura Paisagista em Portugal”, in T. Andresen ed., Do Estádio Nacional ao Jardim Gulbenkian. Francisco Caldeira Cabral e a primeira geração de arquitectos paisagistas (1940-1970), Lisboa, Fundação Calouste Gulbenkian: 18-97.

Billig, M. 1995, Banal Nationalism, Los Angeles, Sage.

Carvalho, L. M. de 2016, “Benfica e Torino recordam tragédia de 1949: Dignos destes campeões: Homenagem realizou-se no Estádio Nacional”, <http://www.maisfutebol.iol.pt/tragedia-desuperga/eusebio-cup/benfica-e-torino-prestam-homenagem -aos-herois-de-1949>, 27 July 2016, accessed 16 April 2018.

Certeau, M. de 1984, The Practice of Everyday Life, Berkeley, University of California Press.

Coelho, J. N. and Pinheiro, F. 2002, A paixão do povo: história do futebol em Portugal, Porto: Edições Afrontamento.

Cruz, L. A. S. F. da 2005, o Estádio Nacional e os novos paradigmas do culto. Miguel Jacobetty e a sua época, MA dissertation, Lisboa, Universidade Lusíada de Lisboa.

Domingos, N. \& Kumar, R. 2011, “A grande narrativa desportiva: o desporto nos média em Portugal”, in J. Neves and N. Domingos eds., Uma história do desporto em Portugal, t. I, Corpo, espaços e média, Vila do Conde, Quidnovi: 207-310. 
O Estádio Nacional (Official Programme for the Opening Ceremony of the National Stadium on June 10 1944), accessed 12 April 2018. http://aterrememportugal.blogpsot.co.uk/2013/06/ inauguracao-do-estadio-nacional-em-1944.html.

Frier, D. and Woods, P. 2017, We'll Always Have Lisbon: Celtic's Glory Year 1967, [Sandford], David G. Frier.

Hutton, P. H. 2018, "Philosophical Reflections on the Ways of Memory and History", History and Theory, 57 (2): 292-305.

Inglis, S. 1990, The Football Grounds of Europe, London, Willow Books.

Lefebvre, H. 1991, The Production of Space, translated by Donald Nicholson-Smith, Oxford, Blackwell Books.

Legg, S. 2005, "Contesting and surviving memory: space, nation, and nostalgia in Les Lieux de Mémoire", Environment and Planning D: Society and Space, 23: 481-504.

Lopes, M. 2015, A ganhar ou a perder: um ano de Sporting, Lisbon, Edições Paquiderme.

Martins, R. A. 2009, Futebol de Causas, [Coimbra], PNG Pictures.

Neves, J. 2004, “As Chuteiras não Têm Pátria: Futebol, Nacionalismo e Tempo”, in J. Neves and N. Domingos eds., A época do futebol. o jogo visto pelas ciências sociais, Lisboa, Assírio \& Alvim: 55-102.

Nora, P. 1996, "Preface to English Language Edition: From Lieux de memoire to Realms of Memory", in Realms of Memory: Rethinking the French Past, Pierre Nora ed., New York: Columbia University Press: xv-xxiv.

Ornelas, J. N. 2002, “The Fascist Body in Contemporary Portuguese Narrative”, in LusoBrazilian Review, 39 (2): 65-77.

Ribeiro, A. L. 1944, Inauguração do Estádio Nacional, Lisboa, SPAC, accessed 11 April 2018. https:// www.youtube.com/watch?v=9jWdZS3ATPc\&t=731s.

Serrado, R. 2009, O jogo de Salazar: a política e o futebol no Estado Novo, Alfragide, Casa das Letras. Stroobant Santos, A. P. R. 2011, Património desportivo e musealização: Elementos para um projeto de musealização do Estádio Nacional, MA thesis, Lisboa, Universidade Lusófona de Humanidades e Tecnologia.

Tiesler, N. C. 2012, "Ensaio sobre a Festa, o Futebol e a 'Batalha dos Nacionalistas': Uma Bandeira Não É uma Bandeira Não É uma Bandeira Não É uma Bandeira", in N. Domingos \& N. C. Tiesler eds., Futebol Português: Política, Género e Movimento, Porto, Edições Afrontamento: 325-338.

Tomaz, J. and Adão e Silva, P. 2017, Deixem-nos sonhar. Caso Saltillo: Portugal e o México 86, Lisboa, Tinta da China.

\section{NOTES}

1. The basic outline of the stadium is already recognisable in a sketch of 1938 reproduced by Andresen (2003: 38), bearing the signatures of German architect Konrad Wiesner and the German-trained Francisco Caldeira Cabral. The final design of the central Presidential Box at the stadium, however, was the work of Miguel Jacobetty Rosa (see Cruz 2005: 76-77).

2. For further information on this facility, see Inglis (1990: 54-55). 
3. From Salazar's address to the sportsmen of the nation on 3 December 1933, reproduced in a propaganda poster issued by the Secretariado da Propaganda Nacional (National Office for Propaganda), accessed on 12 April 2018. www.oliveirasalazar.org/imagem.asp?id=6994.

4. It is no coincidence that Lopes Ribeiro's documentary concludes with a focus on the Olympic flame lit at the south end of the stadium on the day: in wartime, the 1940 and 1944 modern Olympiads had been cancelled, in keeping with the classical tradition of not holding the Olympiad during a time of conflict, and this final focus on the Olympic flame thus supports the narrative that Portugal was a haven of peace in a war-torn continent.

5. View, for example, the contrast between the photographs from the 1940s reproduced on the Restos de Colecção website, accessed on 29 October 2018, http://restosdecoleccao.blogspot.com/ 2013/05/estadio-nacional.html, and photographs taken in the 1960s, such as that of the Académica de Coimbra team line-up before the 1969 Portuguese Cup Final, clearly showing the fully grown woodland around the stadium in the background (Curado 2012).

6. See online reports in the Diário de Lisboa, 10 June 1944 (1) and 11 June 1944 (4), which described the match as a "luta nobre" (a noble struggle) between the two teams, accessed on 21 November 2018. http://casacomum.org/cc/visualizador?pasta=05774.038.09684 and http://casacomum.org/ cc/visualizador?pasta=05774.038.09686\#!4.

7. Resende, S. 1967, “A Primeira Vitória: Europa Unida Sob o Signo do Futebol”, A Bola, 25 May 1967: 1 and 8 (8). Similar sentiments were also expressed in an anonymous article in the Diário de Notícias, "O Maior Acontecimento Desportivo de Sempre em Portugal”, Diário de Notícias, 25 May 1967: 7.

8. A Bola published a short article criticising the unexpected absence of the Portuguese players from the post-match banquet at the Avenida Palace Hotel in Lisbon; see "O banquete efectuou-se sem a comparencia dos jogadores portugueses”, A Bola, 26 May 1947: 5; for a more recent discussion of the circumstances surrounding this match, see also Coelho and Pinheiro (2002: 345). 9. Neves recognises in principle Billig's argument concerning the potential for easy slippage in discourse between the banal nationalism of everyday life and the more aggressive assertions of nationalism in sports reporting (where he highlights the use of warlike metaphors in the coverage given to international fixtures) (Billig 1995: 123-124), but he (Neves) clearly does not see this as a serious threat in modern Portuguese politics, citing the failure of the PDS-PP to appropriate Portugal's relative success in EURO 2004 into a political movement called Força Portugal (“Go Portugal!") on the model of Silvio Berlusconi's successful Forza Italia movement (Neves 2004: 95).

10. Quoted from the Diário das Sessões da Assembleia Nacional, no. 136, 14 March 1952 (537538), in Agoas and Gomes (2011: 185).

11. See the RTP report on this incident, accessed on 3 April 2018. http://ensina.rtp.pt/artigo/aultima-ovacao-a-marcelo-caetano/.

12. See A Bola, 1 April 1974.

13. For a fuller discussion of the student revolt in Coimbra in 1969, particularly in relation to the Portuguese Cup Final, see the documentary film Futebol de Causas ("Football with a Cause") (Martins 2009).

14. Contrary to practice in most other countries, the presentation of the Taça de Portugal to the captain of the winning team was not made to him alongside his own victorious teammates, but alongside the captain of the defeated team, thus emphasising the spirit of fraternity gained through sport rather than the rivalry between different clubs. This practice was maintained at least until 1987 (as demonstrated by a photograph of the presentation of the trophy to shéu of Benfica, reproduced in Coelho and Pinheiro 2002: 596). For further discussion of the 1969 Final, see, for example, A Bola 2014, “Com Artur Jorge preso no quartel”, Suplemento de A Bola: "Estádio Nacional, 70 Anos", 15 May 2014: S05, and Curado P. 2012, “Em 1969, a Académica perdeu a Taça mas foram os estudantes que festejaram”, Público, 20 May 2012, accessed on 1 November 
2018. https://www.publico.pt/2012/05/20/jornal/em-1969-a-academica-perdeu-a-taca-masforam-os-estudantes-que-festejaram-24573489.

15. A Bola, 21 June 1969: 5.

16. A Bola, 10 July 1967: 4.

17. A Bola, 23 June 1969: 1.

18. See "Os estudantes de Coimbra 'invadiram' Lisboa para assistir à Final da Taça”, Diário de Lisboa 22 June 1969: 1 and 17. http://casacomum.org/cc/visualizador?pasta=06602.140.23695\#!23, accessed on 11 April 2018. The article closes with a quotation from one anonymous fan and an ellipsis inviting the astute reader to read his/her own conclusions into the reported remarks: "Não há dúvida que a festa desta tarde não é só a festa do futebol - mas muito mais do que isso. 'E que haja justiça'; (como nos disse um elemento desse grupo), 'mesmo que em futebol seja o Benfica a ganhar'..." ("There is no doubt that this afternoon's party is not just a party about football - but a lot more than that. 'And let justice be done' (as one member of that party told us) 'even if in the football it is Benfica who win'...") (17).

19. Cited in A Bola 2014, "Com Artur Jorge preso no quartel", Suplemento de A Bola: "Estádio Nacional, 70 Anos", 15 May 2014: S05.

20. This symbolic importance is reflected in the prominent display on the club website of two images from the 1969 Final, one of supporters at the match prominently displaying banners calling for "Menos policias" ("Fewer policemen") and a "Universidade Livre" ("Free University"). See the Académica de Coimbra website, accessed on 16 April 2018. http://www.academicaoaf.pt/.

21. See A Bola, 13 June 1974: 1.

22. Diário de Lisboa, 16 June 1975: 18, accessed on 5 November 2018. http://casacomum.org/cc/ visualizador?pasta=06823.173.27258\#!18.

23. See the publicity poster for the event reproduced on the website of the Fundação Mário Soares, accessed on 31 October 2018. http://casacomum.org/cc/visualizador?pasta=09845.305.

24. See a commercial posting on the club's website dated 2 July 2018, accessed on 31 October 2018. http://cdaves.pt/rumo-ao-jamor-o-filme/.

25. The last international match played at the National Stadium was a 1-1 draw vs. Sweden on 12 October 1986.

26. See also the "Memória Descritiva do Projecto Definitivo das Bancadas do Estádio de Atletismo" ("Descriptive Memorandum of the Final Project for the Stands of the Athletics Stadium"), by Konrad Wiesner and Caldeira Cabral, dated October 14 1939, reproduced by Stroobant Santos (2011: 120).

27. The stadium received serious criticism in the Scottish press after the 1967 European Cup Final in terms of media facilities, control of tickets and the chaotic scenes which surrounded the presentation of the trophy after the match (Frier and Woods 2017: 125-126).

28. A Bola, 11 February 1967: 1.

29. "Acreditar no Vale do (J)amor" (Faith in the Jamor Valley/ The Valley of Love), Centro Portugal Desporto, supplement of the Diário de Aveiro, 18 June 1999: II. The title of the article depends for its effect on the similarity between the name of the river valley and the Portuguese word for "love" and also implicitly plays on the strength of the association within Portuguese culture with the Island of Love in Cantos IX and X of Camões' epic poem Os Lusíadas (The Lusiads).

30. “Crónicas da Taça”, O Século Ilustrado, 15 July 1967: 9.

31. A Bola, 19 June 1978: 1-4.

32. Centro Portugal Desporto, supplement of the Diário de Aveiro, 18 June 1999: II.

33. Centro Portugal Desporto, supplement of the Diário de Aveiro, 7 May 1999: V.

34. Diário de Aveiro 1999, “Megapiquenique 'amarelo' vestiu pinhal do Jamor”, 20 June 1999: 17.

35. See, for example, the Celticwiki website, accessed on 1 November 2018. http:// www.thecelticwiki.com/page/Estadio+Nacional+-+Pictures. This page features numerous 
photographs taken by Celtic fans at the National Stadium before the club's Champions League match against Benfica on 1 November 2006.

36. See Ferreira, A. 2017, “Celtic Invadiu o Jamor”, Record, 26 May 2017: 11.

37. See Perestrelo, N. 2017, "Celtic: O Santuário dos Leões de Lisboa”, A Bola, 28 April 2017: 20-21.

38. See, for example, Carvalho (2016), and "Torino a Lisbona dopo 67 anni: Il Grande Toro Rivive al Stadio da Luz", dated 28 July 2016, on the Il Posticipo website of the Italian sports newspaper La Gazzetta dello Sport, accessed on 16 April 2018. http://ilposticipo.it/calcio/grande-torino-eusebiocup/ This report features images from the match at the National Stadium itself.

\section{ABSTRACTS}

This article examines Lisbon's National Stadium (opened in 1944, amidst strong expressions of nationalistic pride) in the light of Pierre Nora's concept of lieux de mémoire, while taking issue with his (and others') insistence on the primacy of national identity. A flexible use of the stadium, not as a fixed monument, but rather as a blank canvas onto which successive generations of football fans have imposed their varying memories and subjective identities (examined through press reports and other contemporary sources), enables the site to retain its place in the popular imagination, in spite of its past political associations.

Este artigo analisa o Estádio Nacional de Lisboa (inaugurado em 1944, com uma ênfase marcadamente nacionalista) à luz do conceito de lieux de mémoire de Pierre Nora, com uma adaptação da insistência de Nora (e de outros académicos) na primazia da nacionalidade como sinal da identidade coletiva. Um uso flexível do estádio, não como monumento fixo, mas sim como uma tela em branco sobre a qual gerações sucessivas de adeptos do futebol projetaram suas próprias memórias e identidades subjetivas (examinadas através da imprensa desportiva e de outras fontes contemporâneas), permite que o Estádio mantenha um lugar forte na imaginação popular, apesar das associações políticas do passado.

Cet article analyse le Stade national de Lisbonne (inauguré en 1944, lors d'une cérémonie résolument nationaliste) à la lumière du concept de lieux de mémoire de Pierre Nora, en adaptant un point sur lequel a insisté Nora (et d'autres chercheurs) : le primat de la nationalité comme signe de l'identité collective. Un usage flexible du stade, appréhendé non pas comme un monument fixe, mais plutôt comme une toile vierge sur laquelle des générations successives de supporters de football ont projeté leurs propres mémoires et identités subjectives (examinées à travers la presse sportive et d'autres sources contemporaines), a permis à ce lieu de conserver une position privilégiée dans l'imaginaire populaire, en dépit des associations politiques du passé.

\section{INDEX}

Palavras-chave: estádio nacional, Portugal, desportos, Pierre Nora, espaço, memória, identidade colectiva

Keywords: national stadium, Portugal, sports, Pierre Nora, space, memory, collective identity Mots-clés: stade national, Portugal, sports, Pierre Nora, espace, mémoire, identité collective 
AUTHOR

DAVID G. FRIER

University of Leeds, UK

D.G.Frier[at]Leeds.ac.uk 